\title{
Popularization of Cumin cv. GC 4 through Front Line Demonstrations in Pali District of Rajasthan, India
}

\author{
Y. K. Sharma ${ }^{1} *$ and M. L. Meena ${ }^{2}$ \\ ${ }^{1}$ Department of Extension Education, SKN, AU, Collage of Agriculture, Lalsot, Dausa \\ (Rajasthan) 303503, India \\ ${ }^{2}$ SMS (Agricultural Extension) ICAR-CAZRI, Krishi Vigyan Kendra, Pali-Marwar \\ (Rajasthan) 306401, India
}

*Corresponding author

\begin{tabular}{|l|}
\hline K e y w o r d s \\
$\begin{array}{l}\text { Adoption, frontline } \\
\text { demonstration, } \\
\text { farmers' } \\
\text { satisfaction, } \\
\text { economic analysis } \\
\text { and cumin }\end{array}$ \\
\hline Article Info \\
\hline $\begin{array}{l}\text { Accepted: } \\
\text { 18 August } 2019 \\
\text { Available Online: } \\
\text { 10 September } 2019\end{array}$ \\
\hline
\end{tabular}

A B S T R A C T

Cumin is one of the important major seed spice crops, considered to be a remunerative cash crop mainly grown in the western part of the country particularly in Rajasthan and Gujarat occupying about 8.8 lakh hectares area with annual production of about 4.9 lakh tonnes. Frontline demonstration is one of the most important and powerful tools for transfer of technology. Keeping in view of effective extension approach of FLDs for dissemination of technology FLDs on cumin conducted by KVK, Pali, Rajasthan was assessed. The yield and economic performance of frontline demonstration, horizontal spread of technology, extent of adoption level and their extent of satisfaction level of respondent farmer over extension services and performance of demonstration was measured in this study. It was observed that there was 27.3 to 41.3 per cent increase in grain yield over local check and the average benefit cost ration was higher under demonstration as compared to control plots during the all years of the study. It was found estimated that the horizontal spread of cumin cv. GC 4 from about 150 ha during 2011-12 to 5100 ha during the year 2017-18. The findings of the study also revealed that they had increase in adoption level ranging from 09.4 per cent of sowing time and method to 46.9 percent of improved and quality seed after conducting the FLD programmes. The majority of the respondent farmers expressed high extent level (51.2\%) to the medium (34.4\%) level of satisfaction for extension services and performance of technology under demonstrations. It can be concluded that frontline demonstrations conducted under the close supervision of scientists is one of the important tool for extension to demonstrate newly released crop production and protection technologies and its management practices in the farmer's field under different agro-climatic region and farming situations. The improved variety GC 4 with recommended package of practices can be recommended in western Rajasthan for successful cultivation of cumin for fulfilling the demand of domestic and export markets. 


\section{Introduction}

Indian spices and spicy food is popular world over from ancient time. Traders from across the world have visited our sub-continent for spices; nearly 76 spices are grown in India. Seed spices are annual crops whose seeds are consumed as spice, viz. coriander, cumin, fenugreek, fennel, ajwain, dill, anise, nigella, caraway celery etc. These seed spices make food tasty and luxurious, and also bear medicinal value. Interestingly, these crops are predominantly grown in semi-arid and arid zone of the country having dry or wet cool weather conditions. Together the states of Rajasthan and Gujarat and parts of Madhya Pradesh can be called as the "bowl of seed spices" contributing more than $80 \%$ of the country's annual production. Seed spices possess significant importance as domestic and export commodity. There has been a gradual rise in area and production of these crops, emphasizing more on the major crops like cumin, coriander, fennel and fenugreek a clear enhancement is visible both in area and production including productivity in the last 25 years (Singh and Solanki 2015). Coriander and cumin covers nearly $80 \%$ of the seed spice area and production. The global demands for India Spices are increasing day by day. In terms of export, there is increase of $29 \%$ in coriander, $70 \%$ in cumin, $58 \%$ in fennel and $49 \%$ in fenugreek. There is a huge demand for Indian spices all over the world.

Cumin (Cuminum cyminum L.) belonging to family Apiaceae, is one of the important major seed spice crops grown mainly in Rajasthan and Gujarat states of the country. Annually, it is grown in about 8.8 lakh hectares area producing about 4.9 lakh tonnes (GOR 201718). Average national productivity of this crop is remaining very less (596 kg ha-1) due to low level of awareness among the farming community about area specific recommended package of practices, less availability of high yielding and resistant varieties, lower adoption of recommended plant production and protection technologies. Introduction of high yielding varieties tolerant to diseases can do the wonders in the growing area. Application of appropriate doses of fertilizers at right time with other recommended practices (irrigation and intercultural operations etc.) also play a crucial role with respect to the productivity of cumin (Lal 2013).

Besides these, effective management of biotic and a-biotic stresses at crucial time with the help of available chemicals and organic means is also very important to increase the productivity and production of the crop. Pali, situated in the arid fringes of Rajasthan, represented by sandy loam to loamy silt soil with temperature range from 2 to $48^{\circ} \mathrm{C}$ and receives about $420 \mathrm{~mm}$ rainfall annually. The farmers of this district are trying to adopt the improved varieties and scientific technologies, however many of them still doing the farming with available local varieties and conventional practices. The field demonstrations conducted under the close supervision of scientists of the National Agriculture Research System is called front line demonstrations because the technologies are demonstrated for the first time by the scientists themselves before being fed in to the main extension system of the State Department of Agriculture. The main objective of front line demonstrations is to demonstrate newly released crop production and protection technologies and its management practices in the farmers' field under different agro-climatic regions and farming situations. While demonstrating the technologies in the farmers' field, the scientist are required to study the factors contributing higher crop production, field constraints of production and thereby generate production data and feedback information. Realizing the importance of FLDs in transfer of latest technologies, CAZRI, Krishi Vigyan Kendra, Pali have regularly been conducting FLDs on 
cumin at farmers field in different villages of Pali district of Rajasthan with the objective of convincing farmers and extension functionaries together about the production potentialities of production technologies for further wide scale diffusion. Keeping in view of an effective extension approach of FLDs for dissemination of cumin technology, it was thought that impact of FLDs conducting by KVK, Pali was to be assessed.

\section{Materials and Methods}

The frontline demonstrations on cumin were conducted by several institutes or organizations in Rajasthan but due to paucity of time and proximity, study was confined to Front Line Demonstrations (FLD) conducted by KVK in Pali district of Rajasthan. The data on output were collected from FLDs plots and finally the grain yield; cost of cultivation, net returns with the benefit cost ratio was work out. For the purpose of investigation, 20 villages from 4 blocks (each block 5 villages) they were leading cumin production of Pali district where FLDs on cumin were conducted during preceding seven years (Rabi 2011-12 to 2017-18) were selected. A comprehensive list of FLD farmers was prepared. Out of this, 8 beneficiaries from each selected village were randomly selected. Thus, a total sample of 160 respondents was taken for the study. The Adoption level of the farmers about improved production practices of cumin before conducting and after conducting FLD was measured. Further, the satisfaction level of respondent farmers about extension services provided was also measured based on various dimensions like training of participating farmers, timeliness of services, supply of inputs, solving field problems and advisory services, fairness of scientists, performance of variety demonstrated and overall impact of FLDs. The data were collected through personal contacts with the help of well structured interview schedule. The gathered data were processed, tabulated, classified and analyzed in terms of mean percent score and ranks etc. in the light of objectives of the study. The Client Satisfaction Index was calculated as developed by Kumaran and Vijayaragavan (2005).

Client Satisfaction Index

$=\frac{\text { The individual obtained score }}{\text { Maximum score possible }}$

\section{Results and Discussion}

\section{Yield performance of cumin (GC 4)}

During 2011-12 to 2017-18, result of cumin variety GC 4 demonstrations conducted at farmer's field revealed that there was 27.3 to 41.3 percent increase in grain yield over local check. The Table 1 shows that average yield in demonstrations varied from $630 \mathrm{~kg}$ to 790 $\mathrm{kg} / \mathrm{ha}$ during all seven years and highest yield in demonstration was recorded during 2014-15 followed by 2011-12 (630 kg/ha), 2012-13 (700 kg/ha), 2013-14 (650 kg/ha), 2015-16 (720kg/ha), 2016-171 (760 kg/ha) and 2017$18(650 \mathrm{~kg} / \mathrm{ha})$ respectively. In local checks (Table1), also same trend was found i.e., maximum average grain yield $(580 \mathrm{~kg} / \mathrm{ha})$ was recorded during 2016-17 and lowest grain yield $(450 \mathrm{~kg} / \mathrm{ha})$ was observed during 201112. The overall average yield in demonstration plots $(700 \mathrm{~kg} / \mathrm{ha})$ was higher as compared to local plots $(547 \mathrm{~kg} / \mathrm{ha})$ and increase in grain yield was 35.9 percent over local checks during the study period (2011-12 to 2017-18). It might be due the soil type and its moisture availability, rainfall and weather condition as well as the change in the locations of demonstration plots every year. In general, in all the years grain yield of FLDs plots was higher as compared to local check which was due to good variety, seed treatment, recommended fertilizer doses, plant protection measures were followed by the demonstrators and scientists in the demonstrations plots. 
The similar results were also observed by Dayanan et al., (2013), Lal (2014), Meena and Singh (2013) and Sharma and Choudhary (2014). Hence, it can be concluded from the Table 1 that increased yield was due to adoption of improved variety and conducting demonstrations of proven technologies yield potentials of crop can be increased to greater extent.

\section{Economic performance of cumin (GC 4)}

The year wise economics of cumin production under demonstration were estimated and the result has been presented in Table 2 .

The economic analysis of the data over all the years revealed that cumin (GC 4) recorded higher gross returns (86607 Rs.), net returns (59543) and B: C ratio (2.4) as compared to local check.

Further, the Table 2 also shows that the cost of cultivation was more in local checks as compared to demonstrations plots. It was due the fact that farmers were practices to use more seed rate and over doses of fertilizers.

The cost of cultivation increased successively of the years of study in demonstration and local plots due to hike in prices of inputs. The figures in Table 2 clearly explain the significance of cumin (GC 4) demonstration at farmer's field during seven years of study in which greater net returns were obtained under demonstration plots than local checks.

The highest net return was received in the year of 2014-15 (Rs. 71850) and lowest during 2011-12 (Rs. 47750).

The Benefit cost ratio was higher under cumin demonstration as compared to control plots during the all years of study (Table 2). The higher net returns and $\mathrm{B}$ : $\mathrm{C}$ ratio in cumin demonstration might be due to the higher grain yield and better pricing of the produce in the market. The overall average additional net return was Rs. 2114 over local plots. These results in line with the findings of Meena et al., (2012), Meena et al., (2013), Singh (2013), Mehrya and Ramesh (2018), Singh and Sharma (2018), Sharma and Choudhary (2014) and Morwal et al., (2018).

\section{Increase in area under improved varieties (Cumin GC 4)}

The estimated data regarding increase in area under improved variety GC 4 in the Pali of Rajasthan is presented in Table 3. It was observed that the area under improved variety GC 4 was estimated only 150 ha during the year 2011-12 which was horizontally increased and estimated 500 ha (2012-13), 1200 ha (2013-14), 2200 ha (2014-15), 3500 ha (2015-16), 4500 ha (2016-17) and 5100 ha (2017-18) respectively, in the Pali district of Rajasthan.

It was clearly shows that the horizontal spread of GC 4 was from about 150 ha during 201112 to 5100 ha during the year 2017-18 and after introduction of cumin cv. GC 4, it was covered more than 76.5 percent area of the total cumin area in the Pali district during the year 2017-158. It might be due to the fact that the variety GC 4 was superior in term of productivity, no yellowish problem, no powdery mildew attach, no scattering at the time of harvesting and good quality of seeds compared to RZ 19 and RZ 209. The findings confirm with the finding of Lal et al., (2013), Narappa et al., (2018) and Singh et al., (2018).

\section{Extent of Adoption level of farmers}

The data regarding adoption of the improved cumin production technologies were also recorded under two heads like; adoption before conducting and after conducting frontline demonstration. 
Table.1 Yield performance of frontline demonstrations on cumin variety GC 4

\begin{tabular}{|l|l|l|l|l|l|}
\hline Year & $\begin{array}{l}\text { No. of } \\
\text { demonstrations }\end{array}$ & Area (ha) & \multicolumn{2}{|l|}{ Average yield (kg/ha) } & Increase in yield \\
\cline { 3 - 6 } & & Demo. & Local check & (\%) over local \\
\hline $\mathbf{2 0 1 1 - 1 2}$ & 30 & 12 & 630 & 450 & 40.0 \\
\hline $\mathbf{2 0 1 2 - 1 3}$ & 40 & 16 & 700 & 550 & 27.3 \\
\hline $\mathbf{2 0 1 3 - 1 4}$ & 35 & 14 & 650 & 460 & 41.3 \\
\hline $\mathbf{2 0 1 4 - 1 5}$ & 30 & 12 & 790 & 570 & 38.5 \\
\hline $\mathbf{2 0 1 5 - 1 6}$ & 40 & 16 & 720 & 530 & 35.8 \\
\hline $\mathbf{2 0 1 6 - 1 7}$ & 50 & 20 & 760 & 580 & 31.0 \\
\hline $\mathbf{2 0 1 7 - 1 8}$ & 50 & 20 & 650 & 490 & 32.7 \\
\hline Average & $\mathbf{2 7 5}(\mathbf{3 9 . 3})$ & $\mathbf{5 6}(\mathbf{1 5 . 7 )}$ & $\mathbf{1 2 8 0}$ & $\mathbf{5 4 7 . 1}$ & $\mathbf{3 5 . 9}$ \\
\hline
\end{tabular}

Table.2 Economic performance of frontline demonstrations on cumin variety GC 4

\begin{tabular}{|c|c|c|c|c|c|c|c|c|c|}
\hline \multirow[t]{2}{*}{$\begin{array}{l}\text { Year } \\
\text { (Rabi) }\end{array}$} & \multicolumn{2}{|c|}{$\begin{array}{l}\text { Cost } \\
\text { cultivation } \\
\text { (Rs/ha.) }\end{array}$} & \multicolumn{2}{|c|}{$\begin{array}{ll}\text { Gross } & \text { return } \\
\text { (Rs./ha) } & \end{array}$} & \multicolumn{2}{|c|}{$\begin{array}{ll}\text { Net } & \text { return } \\
\text { (Rs./ha) }\end{array}$} & \multirow{2}{*}{$\begin{array}{l}\text { Additio } \\
\text { nal } \\
\text { return } \\
\text { (Rs./ha } \\
\text { ) }\end{array}$} & \multicolumn{2}{|c|}{$\begin{array}{l}\text { Benefit cost } \\
\text { ration }\end{array}$} \\
\hline & IP & FP & IP & FP & IP & FP & & IP & FP \\
\hline 2011-12 & 24700 & 23500 & 72450 & 51750 & 47750 & 282 & 19500 & 2.9 & 2.2 \\
\hline 2012-13 & 25200 & 24500 & 80500 & 6 & 55300 & 3 & 16 & 3.2 & 2.5 \\
\hline 2013-14 & 26800 & 25300 & 81250 & 57500 & 54400 & 32 & 22200 & 3.0 & 2.3 \\
\hline 2014-15 & 26900 & 25100 & 98750 & 71250 & 71850 & 46150 & 25700 & 3.7 & 2.8 \\
\hline 2015-16 & 27800 & 26500 & 90000 & 66250 & 62200 & 39750 & 22450 & 3.2 & 2.5 \\
\hline 2016-17 & 28600 & 27400 & 98800 & 75400 & 70200 & 48800 & 21400 & 3.5 & 2.7 \\
\hline 2017-18 & 29400 & 28600 & 84500 & 63700 & 55100 & 35100 & 20000 & 2.9 & 2.2 \\
\hline Average & 27057 & 25843 & 86607 & 64157 & 59543 & 38429 & 21114 & 3.2 & 2.4 \\
\hline
\end{tabular}

$\mathrm{IP}=$ Improved practice; $\mathrm{FP}=$ Farmer practice

Table.3 Increase in area under improved variety of cumin GC 4 in Pali district of Rajasthan

\begin{tabular}{|l|c|c|}
\hline Year (Rabi) & $\begin{array}{c}\text { Total area of cumin in Pali } \\
\text { district (ha) }\end{array}$ & $\begin{array}{c}\text { Estimated area under improved Cv. } \\
\text { GC 4 in Pali (ha) }\end{array}$ \\
\hline $\mathbf{2 0 1 1 - 1 2}$ & 14664 & 150 \\
\hline $\mathbf{2 0 1 2 - 1 3}$ & 15341 & 500 \\
\hline $\mathbf{2 0 1 3 - 1 4}$ & 12511 & 1200 \\
\hline $\mathbf{2 0 1 4 - 1 5}$ & 16180 & 2200 \\
\hline $\mathbf{2 0 1 5 - 1 6}$ & 20426 & 3500 \\
\hline $\mathbf{2 0 1 6 - 1 7}$ & 13114 & 4500 \\
\hline $\mathbf{2 0 1 7}-18$ & 16121 & 5100 \\
\hline Average & $\mathbf{1 5 4 8 0}$ & $\mathbf{2 4 5 0}$ \\
\hline
\end{tabular}


Table.4 Extent of adoption level of the respondents regarding cumin production technologies

\begin{tabular}{|c|c|c|c|c|c|c|}
\hline \multirow[t]{2}{*}{ Cumin production technology } & \multicolumn{2}{|c|}{ Before FLDs } & \multicolumn{2}{|c|}{ After FLDs } & \multicolumn{2}{|c|}{$\begin{array}{c}\text { Increase } \\
\text { in adoption } \\
\text { level }\end{array}$} \\
\hline & $\mathbf{F}$ & $\%$ & $\mathbf{F}$ & $\%$ & $\mathbf{F}$ & $\%$ \\
\hline Land preparation & 125 & 78.1 & 155 & 96.9 & 30 & 18.8 \\
\hline Seed treatment & 105 & 65.6 & 158 & 98.8 & 53 & 33.1 \\
\hline Improved and quality seed & 65 & 40.6 & 140 & 87.5 & 75 & 46.9 \\
\hline Seed rate and spacing & 75 & 46.9 & 118 & 71.9 & 43 & 26.9 \\
\hline Sowing time and method & 130 & 81.3 & 145 & 90.6 & 15 & 09.4 \\
\hline Irrigation scheduling & 113 & 70.6 & 153 & 95.6 & 40 & 25.0 \\
\hline Scientific weed management & 95 & 59.4 & 142 & 88.8 & 47 & 29.4 \\
\hline Plant protection measures & 50 & 31.3 & 108 & 67.5 & 58 & 36.3 \\
\hline Fertilizer application & 60 & 37.5 & 122 & 76.3 & 62 & 38.8 \\
\hline Harvesting & 110 & 68.8 & 136 & 85.0 & 26 & 16.3 \\
\hline Storage & 90 & 56.3 & 125 & 78.1 & 35 & 21.9 \\
\hline
\end{tabular}

Table.5 Extent of farmers satisfaction of extension services rendered

\begin{tabular}{|l|c|c|}
\hline Satisfaction level & Number of respondents $(\mathbf{F})$ & Percent $(\boldsymbol{\%})$ \\
\hline Low level & 23 & 14.4 \\
\hline Medium level & 55 & 34.4 \\
\hline High level & 82 & 51.2 \\
\hline Total & $\mathbf{1 6 0}$ & $\mathbf{1 0 0 . 0}$ \\
\hline
\end{tabular}

The data in Table 4 revealed that they were followed improved practices of cumin production like; sowing time and method $(81.3 \%)$, land preparation $(78.1 \%)$, irrigation scheduling $(70.6 \%)$, harvesting $(68.8 \%)$, seed treatment $(65.6 \%)$, scientific weed management $(59.4 \%)$, storage $(56.3 \%)$, improved and quality seed $(40.6 \%)$, fertilizer application (37.5\%) and plant protection (31.3\%) before conducting programmes while other farmers were started adopting the improved practices like; improved and quality seed $(46.9 \%)$, fertilizer application $(38.8 \%)$, plant protection $(36.3 \%)$, seed treatment (33.1\%), weeding $(29.4 \%)$, seed rate and spacing (26.9 \%), irrigation scheduling $(25.0 \%)$, storage $(21.3 \%)$, land preparation $(18.8 \%)$, harvesting $(16.3 \%)$ and sowing time and method (09.4\%), respectively. The low level of adoption was found like; sowing time and method and storage due to the farmers were practices of late sowing and high seed rate with closing spacing and over doses of fertilizers in cumin cultivation. The findings of the study also revealed that they had increase in adoption ranging from $09.4 \%$ of sowing time and method to 46.9 percent of improved and quality seed after conducting the training and FLD programmes. This might be due the fact that increasing in knowledge, skills and confidence level of farmers through training programmes on different production technologies of cumin crop like; high yielding variety, seed rate and spacing, seed treatment, soil testing, soil treatment, weeding, plant protection measures, irrigation scheduling, 
fertilizer application and harvesting has helped farmers to improve the yield of cumin crop. The similar results were also reported by Meena et al., (2016) and Morwal et al., 2018).

\section{Farmer's satisfaction}

The extent of satisfaction level of respondent farmers over extension services and performance of demonstrated variety was measured by Client Satisfaction Index (CSI) and results presented in Table 5. It is observed that the majority of the respondent farmers expressed high level $(51.2 \% \%)$ to the medium $(34.4 \%)$ level of satisfaction for extension services and performance of technology under demonstrations. Whereas, very few $(14.4 \%)$ of respondents expressed lower level of satisfaction. The results are in conformity with the results of Meena et al., (2016), Kumaran and Vijayaragavan (2005). The higher to medium level of satisfaction with respect to services rendered, linkage with farmers, and technologies demonstrated etc. indicate stronger conviction, physical and mental involvement in the frontline demonstration which in turn would lead to higher adoption. This shows the relevance of frontline demonstration.

It can be concluded that the FLD is playing one of the important role in motivating the farmers for adoption of production technology resulting in increasing their yield and profit. It was observed that the horizontal spread of cumin cv. GC 4 was from about 150 ha during 2011-12 to 5100 ha and it was covered more than 76.6 percent area of the total cumin area in the Pali district during the year 2017-18.

The farmers were expressed high to the medium level of satisfaction for extension services and performance of technology under frontline demonstrations. They had increase in adoption level after conducting the FLDs.
It can be concluded that frontline demonstration conducted under the close supervision of scientists is one of the important tool for extension to demonstrate newly released crop production and protection technologies and its management practices in the farmer's field under different agro-climatic regions and farming situations.

\section{References}

Chaudhary, M.K., Singh D., Meena M.L. and Tomar P.K. 2015. Economic analysis of frontline demonstrations on cumin: A case in arid zone of Rajasthan. Annals of Arid Zones 52(2):137-139.

Dayanand, Verma R.K. and Mahta S.M. 2012. Boosting mustard production technology through front line demonstrations. Indian Research Journal of Extension Education 12(3): 121-123.

DOR. 2017-18. Vital Agricultural Statistics, Department of Agriculture, Government of Rajasthan.pp 123-129.

Kumaran M. and Vijayaragavan K. 2005. Farmers' satisfaction of agricultural extension services in an irrigation command area. Indian Journal Extension Education, 41(3\&4): 8-12.

Lal G. 2014. Impact of adoption of scientific interventions in fenugreek on grain yield and farmers' income: An assessment by frontline demonstrations in arid zone of Rajasthan. African Journal of Agricultural Research 9(32):2391-2396.

Lal G., Mehta R.S., Singh D. and Chaudhary M. K. 2013. Effect of technological intervention on cumin yield at farmers' field. International Journal of Seed Spices 3(2):65-69.

Meena K.C., and Gupta I. N. 2013. Impact of KVK Training Programmes on Adoption of Garlic Production Technology. Journal of Krishi Vigyan 
1(2): 41-43.

Meena M.L. and Singh D. 2013. On-farm assessment of technological innovation of fennel (Foeniculum vulgare mill) cultivation. Journal of Spices and Aromatic Crop, 22(2):200-202.

Meena M.L., Singh D. and Sharma N.K. 2012. Impact of frontline demonstrations on yield enhancement of cumin: A case in arid zone of Rajasthan. Indian Journal of Extension Education 48(1\&2):103104.

Mehrya M.L. and Ramesh.2018. Impact of frontline demonstrations on cumin farmers in Jodhpur and Nagaur district. Chemical Science Review and Letters 7(26):449-453.

Morwal B.R., Pagaria P., Kantwa S.L. and Das S. 2018. Performance of FLD on yield enhancement of cumin in Barmer district of Rajasthan. Journal of Krishi Vigyan 6(2):176-178.

Narappa G., Negalur R.B., Roopashree D.H., Guruprasad G.S. 2018. Seed Village Programme - A Boon to the Rice Growing Farmers for Variety Replacement with Economic Stability. International Journal of Current
Microbiology and Applied Sciences 7(4):3862-3868.

Sharma R. and Choudhary P. C., 2014. Improvement in wheat productivity through frontline demonstrations. Indian Journal of Extension Education \& Rural Development 22:36-41.

Singh B. and Sharma A.K. 2018. Impact of frontline demonstrations on productivity enhancement of cumin in arid zone. International Journal of Seed Spices 7(2): 72-76.

Singh B. and Solanki R.K. 2015. Status of seed spices research and development in India. Indian Journal of Agricultural Sciences 85(2): 151-156.

Singh D., Chaudhary M.K., Meena M.L., Balai L.P. and C. Kumar.2018. Seed village programme: Ensuring livelihood security of small and seed spices farmers. International Journal of Seed Spices 8(2):48-53.

Singh I. 2013. Impact of frontline demonstration on yield and economics of gram in Burhanpur district of Madhya Pradesh. Indian Journal of Extension Education \& Rural Development. 21:55-59.

\section{How to cite this article:}

Sharma Y. K. and Meena M. L. 2019. Popularization of Cumin cv. GC 4 through Front Line Demonstrations in Pali District of Rajasthan, India. Int.J.Curr.Microbiol.App.Sci. 8(09): 15091516. doi: https://doi.org/10.20546/ijcmas.2019.809.173 